\title{
Hydrogen production from pyrolysis oil using the steam-iron process: a process design study
}

\author{
Mariken Bleeker · Sander Gorter · Sascha Kersten • \\ Louis van der Ham · Henk van den Berg • \\ Hubert Veringa
}

Received: 2 June 2009/Accepted: 7 June 2009/Published online: 8 July 2009

(C) The Author(s) 2009. This article is published with open access at Springerlink.com

\begin{abstract}
The overall energy efficiency of the production of pure hydrogen using the pyrolysis oil driven steam-iron process is evaluated for different process conditions. The process consists of a two-step process (reduction with pyrolysis oil, oxidation with steam) from which pure hydrogen can be obtained, without purification steps. An optimum energy efficiency of $53 \%$ is achieved when the equilibrium conversion is obtained in the redox cycle at $800^{\circ} \mathrm{C}$. When assuming chemical equilibrium, increasing the process temperature results in a low process efficiency due to a large amount of unreacted steam that needs to be condensed to separate the hydrogen product. Using experimental data in the process simulation, a high-energy efficiency is obtained at $920^{\circ} \mathrm{C}(39 \%)$ compared with the efficiency at $800^{\circ} \mathrm{C}(29 \%)$. This is caused by the low conversion in the reduction at $800^{\circ} \mathrm{C}$. Improving the iron oxide material to enhance the reduction with pyrolysis oil at $800^{\circ} \mathrm{C}$, is therefore suggested.
\end{abstract}

Keywords Hydrogen - Biomass - Steam-iron process . Pyrolysis oil

M. Bleeker · S. Gorter · S. Kersten $(\bowtie) \cdot$ L. van der Ham .

H. van den Berg

University of Twente,

P.O. Box 217, 7500 AE Enschede, The Netherlands

e-mail: s.r.a.kersten@tnw.utwente.nl

H. Veringa

University of Eindhoven, P.O. Box 513, 5600 MB Eindhoven,

The Netherlands

\section{Introduction}

The demand for hydrogen worldwide is expected to increase rapidly in existing industries and in new technologies such as fuel cells (Ramage and Agrawal 2004). At this moment, hydrogen is still predominantly produced from fossil fuels (Raissi and Block 2004), but with the problems that go along with the use of these fuels, renewable alternatives are being considered. Proposed routes for producing hydrogen from solid biomass contain a substantial amount of different reaction steps (Fig. 1) (Spath et al. 2003) mainly to purify the hydrogen from gaseous to solid byproducts. In the high temperature shift (HT shift) and low-temperature shift (LT shift) CO reacts with steam to $\mathrm{CO}_{2}$ and $\mathrm{H}_{2}$. The $\mathrm{CO}_{2}$ is finally separated from the hydrogen product by pressure swing adsorption (PSA). Typical projected hydrogen from biomass process efficiencies are in the range of 50-58\% (LHV based) (Hamelinck and Faaij 2002). The purification of the gas involves several steps and, therefore, alternative processes, which require none or less purification, can be beneficial.

Biomass can be converted into pyrolysis oil by the fast pyrolysis process, before using it in the production of hydrogen. Liquefying biomass with the pyrolysis process results in a better intermediate energy carrier with a higher volumetric energy density compared with solid biomass (typically $20 \mathrm{GJ} / \mathrm{m}^{3}$ compared with $4 \mathrm{GJ} / \mathrm{m}^{3}$ ) (Bridgwater 2002, 2004). Another advantage of pyrolysis oil compared to solid biomass is that it contains hardly any metals or minerals, and therefore reduces negative effects on catalysts, such as poisoning, when being processed. However, it does not meet the requirements of a transportation fuel (Bridgwater 2004) and further upgrading or processing of pyrolysis oil is required. Furthermore, the energy efficiency of the pyrolysis process is in the range of $70 \%$; thus, the 
Fig. 1 Schematic representation of a proposed route for hydrogen production from biomass (Spath et al. 2003)

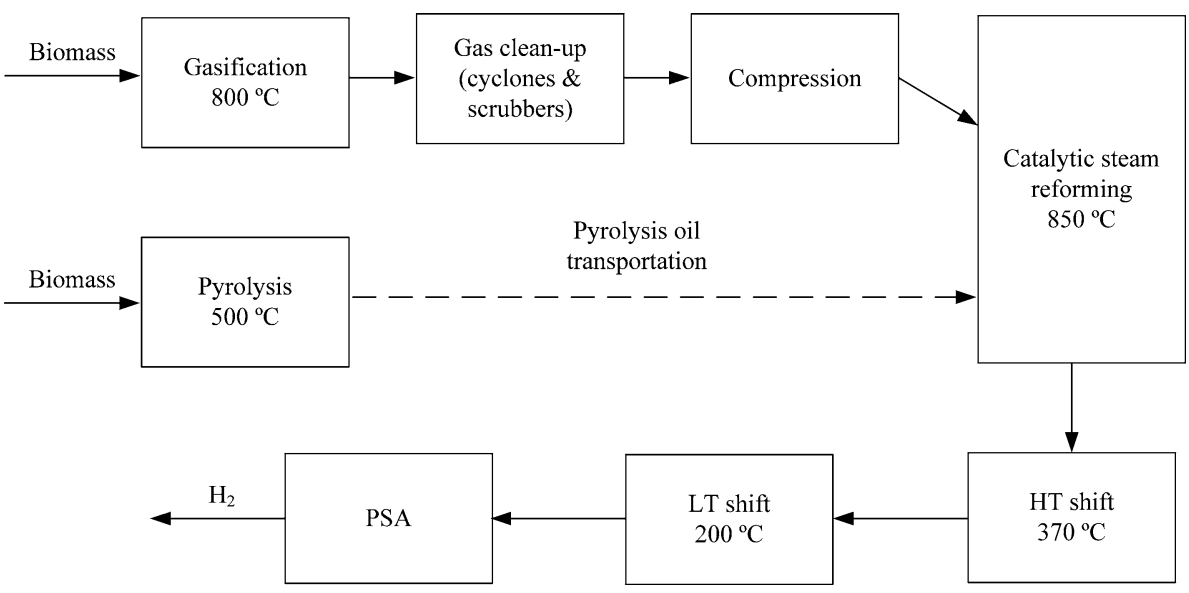

mentioned benefits should outweigh the loss of energy in the pyrolysis process.

The route in which the biomass is converted to hydrogen directly or via the production of pyrolysis oil is shown in Fig. 1. In a previous paper, promising results for the production of hydrogen from pyrolysis oil via the steam-iron process were reported (Bleeker et al. 2007). In a redox cycle with iron oxides, pure hydrogen is produced in the oxidation of wustite $\left(\mathrm{Fe}_{0.945} \mathrm{O}\right)$ with steam. This wustite is formed in a separate step in which magnetite $\left(\mathrm{Fe}_{3} \mathrm{O}_{4}\right)$ is reduced with pyrolysis oil. In Fig. 2, a schematic overview of the proposed concept is shown and the two-step redox cycle replaces the catalytic reforming, HT shift, LT shift and the PSA.

The main advantage of this two-step process is the relative simplicity of the process design. The gasification and reduction can be performed in one single step, by spraying the oil directly over a bed of catalytic or non-catalytic iron oxides (Bleeker et al. 2007). The second step, the oxidation, results in the formation of hydrogen and there is no difficult or expensive separation steps required, because the hydrogen product is essentially CO free. This is important, because CO can poison the fuel cell (Cheng et al. 2007). The disadvantage of the process could be the recirculation of the iron oxide solids, which can be substantial when an optimal conversion of the pyrolysis oil in the reduction, is desired (Bleeker et al. 2007).
In the present study, a technical evaluation of the industrial applicability of such a system is performed. A structural design method (Chilukuri et al. 2007) (Fig. 3) is applied to develop a process flow sheet. The process conditions are selected from experimental and theoretical data (based on thermodynamics) and used to evaluate the process. Simulation results from flowsheet program Aspen Plus ${ }^{\mathrm{TM}}$ are linked with models created in Microsoft Excel to develop mass and heat balances for the process. These combined balances are used to compare process efficiencies at different process conditions $(T$ and $P$ ) and configurations.

\section{Reaction principle: redox cycle using pyrolysis oil}

The steam-iron cycle is a looping process, in which iron oxides are subsequently reduced and oxidized in two separate steps (Bleeker et al. 2007; Tarman and Biljetina 1979; Hacker et al. 2000). In this paper, pyrolysis oil is used as reducing feedstock. The oxidation is performed with steam and results in a $\mathrm{H}_{2} / \mathrm{H}_{2} \mathrm{O}$ mixture, from which the hydrogen can be easily separated by condensing the steam (Fig. 4).

The reactants that contribute to the reduction of the iron oxides are $\mathrm{CO}, \mathrm{H}_{2}$ and solid carbon, Table 1 (Bleeker et al. 2007). The reduction reactions in Table 1 are all reversible reactions and the equilibrium compositions between the
Fig. 2 Hydrogen production from pyrolysis oil using the steam-iron process, in which gasification/reduction is taking place simultaneously

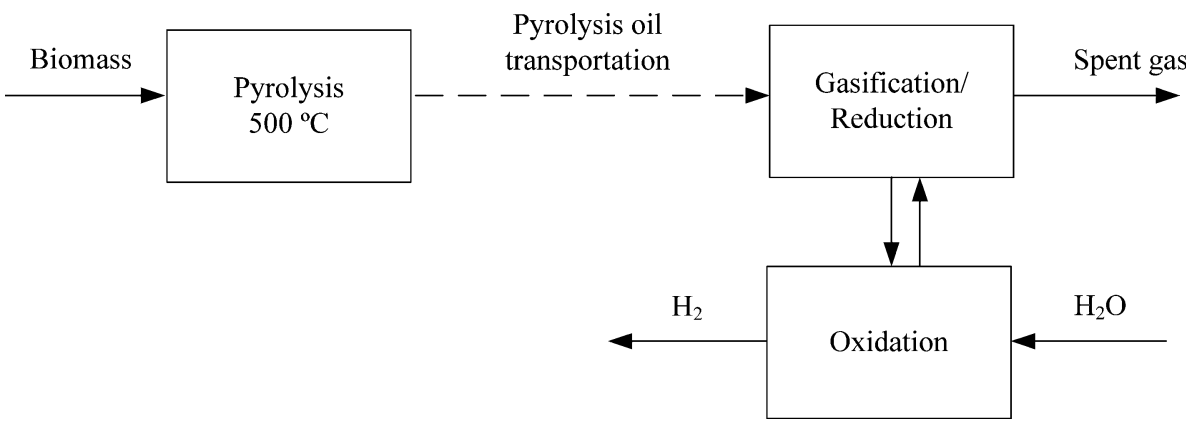




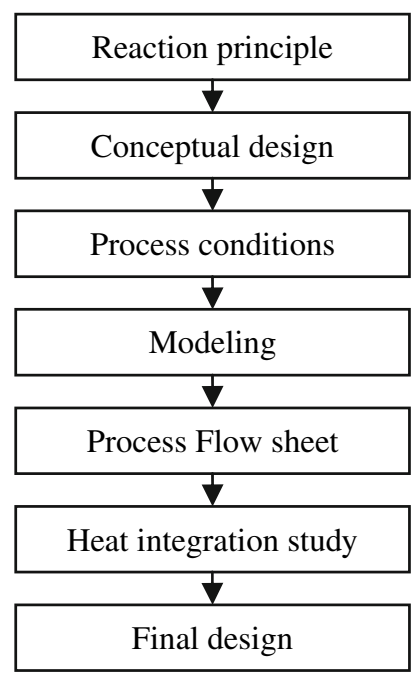

Fig. 3 Steps to create a process design (Chilukuri et al. 2007)

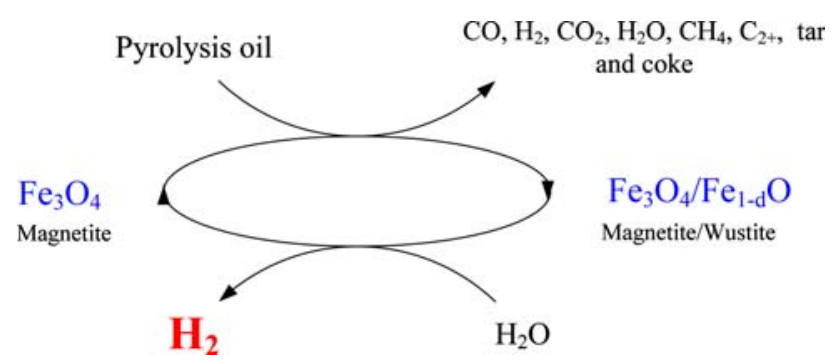

Fig. 4 Reaction cycle for steam-iron process (Bleeker et al. 2007)

gaseous reactants and products $\left(\mathrm{CO} / \mathrm{CO}_{2}\right.$ and $\left.\mathrm{H}_{2} / \mathrm{H}_{2} \mathrm{O}\right)$ are mainly temperature-dependent. The equilibrium gas composition for reactions 1, 2, 4 and 5 is shown in the so-called Bauer-Glaessner diagram (Fig. 5). The reducing potential of the pyrolysis oil depends on the $\mathrm{CO} / \mathrm{CO}_{2}$ and $\mathrm{H}_{2} / \mathrm{H}_{2} \mathrm{O}$ ratio in the gas phase and the amount of carbon formed when the oil is gasified. The $\mathrm{CO} / \mathrm{CO}_{2}$ and $\mathrm{H}_{2} / \mathrm{H}_{2} \mathrm{O}$ ratios obtained after the gasification of oil need to be higher than the equilibrium ratio and the difference between the obtained $\mathrm{CO} / \mathrm{CO}_{2}$ or $\mathrm{H}_{2} / \mathrm{H}_{2} \mathrm{O}$ ratios and the equilibrium ratio determine the reduction potential.
By spraying the pyrolysis oil directly over the iron oxide bed, carbonaceous compounds can deposit on the iron oxide particles and contribute to the reduction in the iron oxide via reactions 3 and 6 . Hydrocarbons can also contribute to the reduction reaction if they are converted to $\mathrm{CO}$ and $\mathrm{H}_{2}$ by steam reforming reactions (Hacker 2003).

The equilibrium data given in Fig. 5 show that the reduction is positively influenced with increasing temperature; and consequently, the oxidation with steam is negatively influenced with increasing temperature. This leads to an optimal temperature for the redox process.

The hydrogen product has to be delivered at a minimum of 20 bar for commercial purposes, but the compression of hydrogen is expensive and energy consuming (Yanga and Ogdena 2007). A high process pressure will result in less compression costs, but can lower the hydrogen production potential. Therefore, the efficiencies at a low and high pressure process condition need to be compared.

\section{Conceptual design}

The process can be divided into two separate parts. First step is the reduction reaction, where iron oxide is reduced with pyrolysis oil. The products of the reduction are essentially $\mathrm{CO}_{2}$ and $\mathrm{H}_{2} \mathrm{O}$, because these are the products of the reduction reactions. Furthermore, unreacted tar, coke, hydrocarbons, $\mathrm{CO}$ and $\mathrm{H}_{2}$ can be expected and can be reused in the reduction or used for energy supply in the process. Recycling of the spent reducing gas will only be effective when (part) of the reduction products $\left(\mathrm{CO}_{2}\right.$ or $\mathrm{H}_{2} \mathrm{O}$ ) can be separated or when by-products, such as hydrocarbons, are converted in a recycle by reforming to $\mathrm{H}_{2}$ and $\mathrm{CO}$.

The second step is the oxidation, where the hydrogen is produced from the reaction of steam with the reduced iron oxide. The hydrogen has to be sufficiently pure (99.9 vol\% and $\mathrm{CO}$ free) and has to be delivered at a pressure of minimal 20 bar for commercial purposes. To be able to fulfill the requirement of continuous operation, the iron oxide particles need to be exchanged between the reduction
Table 1 Reduction reactions of magnetite to metal iron

\begin{tabular}{llcc}
\hline No. & Reaction & $\begin{array}{l}\Delta H_{\mathrm{r}\left(T=827^{\circ} \mathrm{C}\right)} \\
(\mathrm{kJ} / \mathrm{mol})\end{array}$ & $\begin{array}{l}\Delta G_{\mathrm{r}\left(T=827^{\circ} \mathrm{C}\right)} \\
(\mathrm{kJ} / \mathrm{mol})\end{array}$ \\
\hline 1 & $1.2 \mathrm{Fe}_{3} \mathrm{O}_{4}+\mathrm{CO} \leftrightarrow 3.8 \mathrm{Fe}_{0.945} \mathrm{O}+\mathrm{CO}_{2}$ & 27 & -5.1 \\
2 & $1.2 \mathrm{Fe}_{3} \mathrm{O}_{4}+\mathrm{H}_{2} \leftrightarrow 3.8 \mathrm{Fe}_{0.945} \mathrm{O}+\mathrm{H}_{2} \mathrm{O}$ & 61 & -5.2 \\
3 & $1.2 \mathrm{Fe}_{3} \mathrm{O}_{4}+\mathrm{C} \leftrightarrow 3.8 \mathrm{Fe}_{0.945} \mathrm{O}+\mathrm{CO}$ & 197 & -27 \\
4 & $\mathrm{Fe}_{0.945} \mathrm{O}+\mathrm{CO} \leftrightarrow 0.945 \mathrm{Fe}+\mathrm{CO}_{2}$ & -20 & 6.0 \\
5 & $\mathrm{Fe}_{0.945} \mathrm{O}+\mathrm{H}_{2} \leftrightarrow 0.945 \mathrm{Fe}+\mathrm{H}_{2} \mathrm{O}$ & 18 & 5.9 \\
6 & $\mathrm{Fe}_{0.945} \mathrm{O}+\mathrm{C} \leftrightarrow 0.945 \mathrm{Fe}+\mathrm{CO}$ & 150 & -16 \\
\hline
\end{tabular}




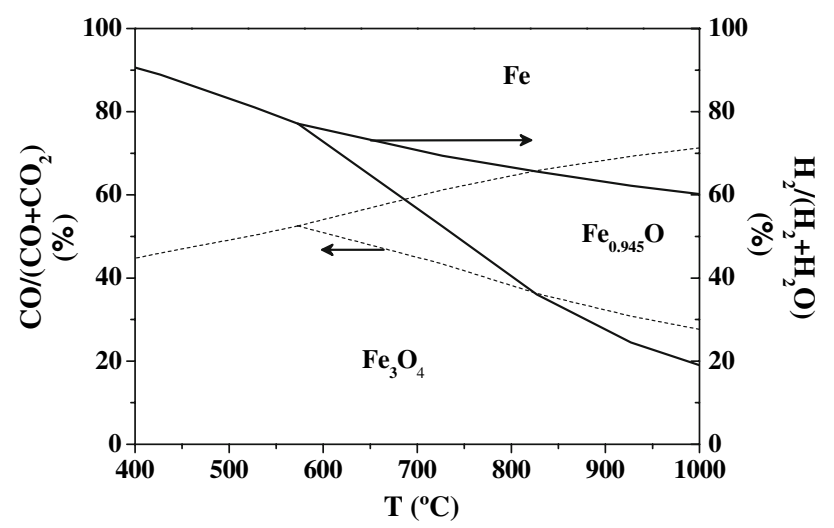

Fig. 5 Bauer-Glaessner diagram: equilibrium compositions of the gases involved in the redox reactions of $\mathrm{H}_{2} / \mathrm{H}_{2} \mathrm{O}$ and $\mathrm{CO} / \mathrm{CO}_{2}$ with $\mathrm{F}_{3} \mathrm{O}_{4}$ (magnetite), $\mathrm{Fe}_{0.945} \mathrm{O}$ (wustite) and $\mathrm{Fe}$ (Bleeker et al. 2007)

and oxidation. Figure 6 shows a schematic representation of this conceptual design.

Both reduction and oxidation are performed in a fluidized bed. In this way, circulation of the iron oxide between the reductor and oxidator can be achieved. Furthermore, heat exchange in a fluidized bed is good, which is important when the pyrolysis oil is gasified directly in the fluidized bed.

The amount of $\mathrm{Fe}_{3} \mathrm{O}_{4}$ that can be reduced by a certain amount of pyrolysis oil is determined in the reduction. This means that the quantity of hydrogen product per amount of pyrolysis oil is determined in the reduction and, therefore, process of optimization starts with the reduction. The efficiency of the process is determined in terms of an overall process energy efficiency, where the heating values of the feedstock and the product are used (Appendix, Table 8), as well as additional energies required in the process as heat or electric power. The definition of the energy requirements of the process steps is given in Table 2 and Fig. 6. Furthermore, heat exchange between the different streams can minimize the overall energy demand of the process.

The net-energy requirement $(Q)$ of the process is used in the calculation of the process energy efficiency. Furthermore, the compression of hydrogen to 20 bar was taken into account in the total process efficiency.

$$
\eta_{\text {process }}=\frac{M_{\mathrm{H}_{2}} \mathrm{LHV}_{\mathrm{H}_{2}}}{\mathrm{LHV}_{\text {oil }}+\frac{Q}{\lambda_{\text {heat }}}+\frac{W_{\text {comp }}}{\lambda_{\text {comp }}}}
$$

where $Q$, the net energy requirement for the process in $\mathrm{MJ} /$ $\mathrm{kg}$ oil; $W_{\text {comp }}$, the net energy requirement for compression of the hydrogen in $\mathrm{MJ} / \mathrm{kg}$ oil; $\lambda_{\text {heat }}$, the efficiency to produce the heat required in the process, a value of $\lambda_{\text {heat }}=0.8$ is used in the calculations; $\lambda_{\text {elec }}$, the electrical efficiency to compress gas, a value of $\lambda_{\text {elec }}=0.4$ is used in the calculations; $M_{\mathrm{H} 2}$, the amount of hydrogen $(\mathrm{kg})$ produced per $\mathrm{kg}$ oil; $\mathrm{LHV}_{\mathrm{H} 2}$ and $\mathrm{LHV}_{\mathrm{oil}}$, the low-heating value of hydrogen $\left(\mathrm{MJ} / \mathrm{kg} \mathrm{H}_{2}\right)$ and oil (MJ/kg oil).
Fig. 6 Conceptual design of the steam-iron process with pyrolysis oil as feedstock

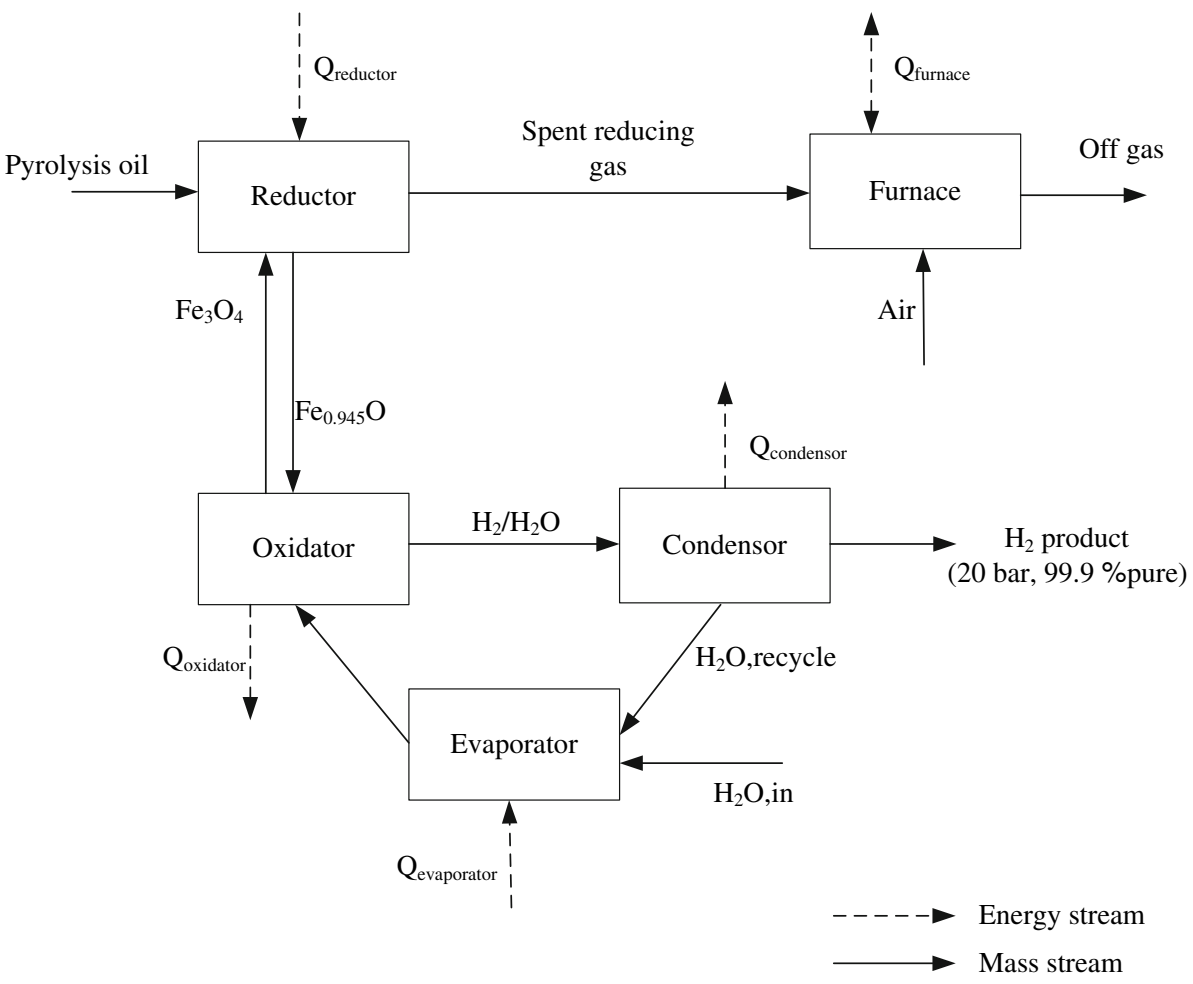


Table 2 Definitions of energy required for the different process steps

$Q_{\text {reductor }}$ Energy demand of the reductor reactor, in which both gasification of oil and reduction take place

$Q_{\text {furnace }} \quad$ Energy demand/production in the furnace after burning the spent gases with an excess of air

$Q_{\text {oxidator }}$ Energy produced in the oxidation

$Q_{\text {evaporator }}$ Energy required to heat water to hot steam

$Q_{\text {condenser }}$ Energy obtained when the hot product gas is condensed

\section{Process conditions selection}

The optimum temperature and pressure have to be determined for the process design. As mentioned earlier, these conditions have an influence on the reaction equilibrium in both reduction and oxidation.

\section{Temperature}

\section{Theoretical approach}

A theoretical approach (based on thermodynamic data), taking hydrogen production as well as energy demands into account, shows an optimum process temperature at $727^{\circ} \mathrm{C}$ (Bleeker, to be published). The process efficiency has a maximum because two temperature effects counteract each other, namely an improved reduction potential with pyrolysis oil at high temperatures and a better steam conversion in the oxidation step at low temperatures.

\section{Experimental approach}

Based on the previous experimental work, the following effects of temperature on the use of pyrolysis oil in the reduction of iron oxide are found:

1. A high temperature is beneficial for the reduction potential of the pyrolysis oil. Experimental studies show that the gasification of pyrolysis oil is strongly temperature-dependent (Bleeker et al. 2007). A drastic increase in the $\mathrm{H}_{2} / \mathrm{H}_{2} \mathrm{O}$ and $\mathrm{CO} / \mathrm{CO}_{2}$ ratios in the gas phase at temperatures above $850^{\circ} \mathrm{C}$ is observed, which is caused by the increase in the reforming of $\mathrm{C}_{2+}$ hydrocarbons as well as the increase in the conversion of oil to the gas phase.

2. Complete conversion of pyrolysis oil to the gas phase can be obtained at high temperatures $\left(>900^{\circ} \mathrm{C}\right)$ over a catalytic iron oxide bed, which is mainly caused by the enhanced reaction of carbon with the iron oxide (Bleeker et al. to be published). A lower temperature results in a lower carbon to gas conversion and in a slow reaction of deposited carbon with the iron oxide.
Following this discussion, it can be concluded that a low temperature $\left(727^{\circ} \mathrm{C}\right)$ is favorable for the redox cycle from a theoretic point of view. However, the experimental data showed that this low temperature is not sufficient to use pyrolysis oil effectively in the redox cycle. The effect of a high and low temperature on the process efficiency will be evaluated at 800 and $920^{\circ} \mathrm{C}$.

Iron oxide to oil mass ratio $\left(\mathrm{Fe}_{3} \mathrm{O}_{4} / \mathrm{oil}\right)$

Besides the temperature, the oil to hydrogen conversion is dependent on the $\mathrm{Fe}_{3} \mathrm{O}_{4}$ /oil ratio. A high $\mathrm{Fe}_{3} \mathrm{O}_{4}$ /oil ratio $(>100)$ results in a low conversion of the iron oxide, which is beneficial for the production of hydrogen. This is caused by the decrease in the reduction rate when the iron oxide is partly reduced resulting in a lower overall pyrolysis to hydrogen production in the process (Bleeker et al. 2007). However, it is energy consuming when large quantities of iron oxide are circulated between the oxidator and reductor. Therefore, a ratio of 60 , which is close to normal circulation rates of solids in biomass gasifiers (Kersten et al. 2003), is chosen. The pumping requirements for the circulation of the iron oxides are not taken into consideration in the present analysis.

\section{Pressure}

Hydrogen has to be delivered at high pressure ( $>20$ bar), which means that the hydrogen product should be compressed when the hydrogen is obtained at a lower pressure. Operating the entire process at high pressure would eliminate this extra step. The purpose of using pyrolysis oil, compared with solid biomass, is to compress it to 20 bar without any difficulties. The effect of pressure on the gaseous reactions take place in the redox cycle, however, should be taken into account.

Literature study shows (Gasior 1961) that a change in pressure does not have any effect on the $\mathrm{H}_{2} / \mathrm{H}_{2} \mathrm{O}$ and $\mathrm{CO} /$ $\mathrm{CO}_{2}$ equilibrium in the Baur-Glaessner diagram. This is logical because the reduction and oxidation reactions with $\mathrm{Fe}_{3} \mathrm{O}_{4}$ and $\mathrm{Fe}_{0.945} \mathrm{O}$ are all equimolar reactions with respect to the gaseous compounds. The reaction rate for the gassolid reactions will probably increase with increasing pressure. The equilibrium of the reduction with solid carbon on the other hand is expected to worsen with increasing pressure.

The gasification of pyrolysis oil at elevated pressure will mainly suppress the reforming of hydrocarbons resulting in a low-reducing capacity of the oil. The hydrogen potential in the redox cycle based on the equilibrium calculations are plotted for different conditions in Fig. 7.

Figure 7 shows a strong decrease in the hydrogen potential when pyrolysis oil is gasified with increasing 


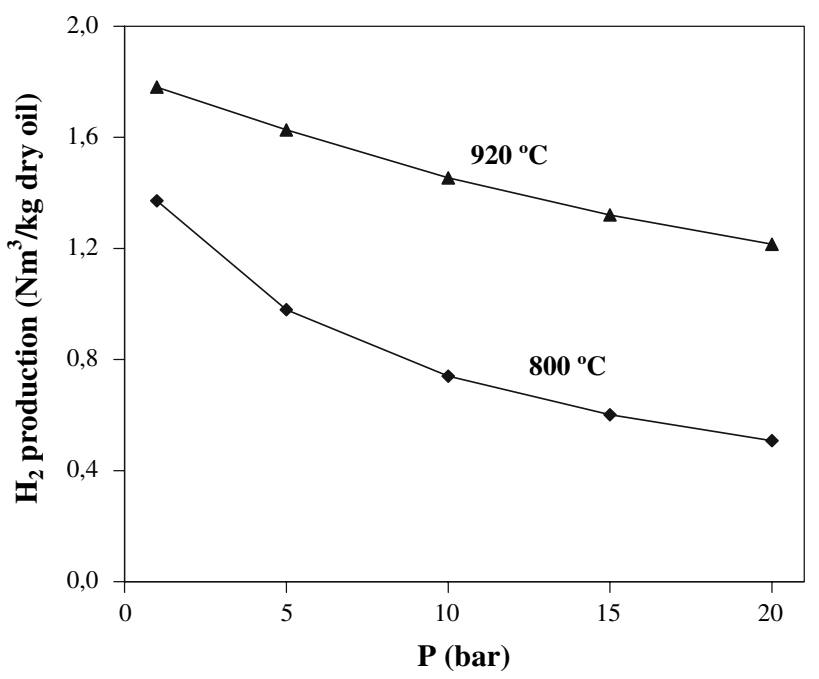

Fig. 7 Hydrogen potential at different temperatures and pressures

pressure at $800^{\circ} \mathrm{C}$. This is caused by the increased formation of hydrocarbons, such as $\mathrm{CH}_{4}$ and $\mathrm{C}_{2}{ }^{+}$, which do not contribute to the reduction. The decrease in the hydrogen production is less significant at a temperature of $920^{\circ} \mathrm{C}$. These results indicate that it is possible to operate this process at a higher pressure of 20 bar, but only if temperatures are high $\left(T>900^{\circ} \mathrm{C}\right)$. This conclusion is, however, only valid when it is assumed that gas equilibrium is obtained in the gas phase when oil is gasified.

\section{Process conditions}

The discussion on the pressure and temperature revealed that three interesting cases need to be evaluated: a high temperature $\left(920^{\circ} \mathrm{C}\right)$ at $1 \mathrm{bar}$; a high temperature $\left(920^{\circ} \mathrm{C}\right)$ at $20 \mathrm{bar}$; a low temperature of about $800^{\circ} \mathrm{C}$ at $1 \mathrm{bar}$ (Table 3). These cases will be evaluated based on the equilibrium assumptions and using experimental data (Bleeker et al. to be published).

The carbon, which is not converted to the gas phase in case $1 \mathrm{~b}$ ( $25 \%$ of the carbon input), is not contributing the reduction reaction, but it is combusted in the furnace for heat production.

\section{Process design}

The conceptual design with functional units is developed into a process flow sheet (Fig. 8). In the process design, the reduction can be recognized in the upper part of the figure. Pyrolysis oil is injected into the reduction reactor, where the oil is gasified and cracked and iron oxide is reduced. The remainder of this reduction gas, which still contains $\mathrm{CO}, \mathrm{H}_{2}, \mathrm{CH}_{4}, \mathrm{C}_{2+}$ and $\mathrm{C}$, is combusted in a furnace with an excess of air. The energy content in the off gas from the furnace is matched to supply the energy required for the gasification/reduction (HE 1) reaction.

Iron oxide particles from the reduction reactor have to be transferred to the other fluidized bed reactor, where they are oxidized with steam to form the desired hydrogen product. The steam feed for the oxidator is preheated with the off gas from the combustor (HE 2) and with the product gas from the oxidator (HE 3). Both heat exchangers operate in the vapor phase and, therefore, an evaporator is used to vaporize the water feed before heat exchange is applied. The hydrogen product is purified by the condensation of the hydrogen-water mixture and, when the process is operating at $1 \mathrm{bar}$, compressed to $20 \mathrm{bar}$.

Process simulation description

Pyrolysis oil gasification is simulated using a Gibb's reactor in Aspen Plus ${ }^{\mathrm{TM}}$ when equilibrium in the gas phase is assumed. The gas composition and carbon obtained from the gasification is used for the calculation of the reduction of the iron oxide. The equilibrium gas composition after the reduction is based on the gas equilibrium ratio of $\mathrm{CO} /$ $\mathrm{CO}_{2}$ and $\mathrm{H}_{2} / \mathrm{H}_{2} \mathrm{O}$ with $\mathrm{Fe}_{3} \mathrm{O}_{4} / \mathrm{Fe}_{0.945} \mathrm{O}$ (Appendix, Table 9). It is assumed in all calculations that the reduction of $\mathrm{Fe}_{3} \mathrm{O}_{4}$ to $\mathrm{Fe}_{0.945} \mathrm{O}$ takes place and that $\mathrm{Fe}$ is not formed.

Table 3 Temperature, pressure and main assumptions used in the reduction reaction for the different cases

\begin{tabular}{llll}
\hline Case name & $T\left({ }^{\circ} \mathrm{C}\right)$ & $P$ (bar) & Assumptions \\
\hline 1a & 800 & 1 & $\zeta_{\text {C to gas }}=100 \%$ : equilibrium in the gas phase for the reaction of $\mathrm{Fe}_{3} \mathrm{O}_{4}-\mathrm{Fe}_{0.945} \mathrm{O}$ \\
1b & 800 & 1 & $\zeta_{\mathrm{C} \text { to gas }}=75 \%$ : equilibrium in the gas phase for the reaction of $\mathrm{Fe}_{3} \mathrm{O}_{4}-\mathrm{Fe}_{0.945} \mathrm{O}$ \\
1 _exp & 800 & 1 & Based on experimental data (Table 4) \\
2 & 920 & 1 & $\zeta_{\mathrm{C} \text { to gas }}=100 \%$ : equilibrium in the gas phase for the reaction of $\mathrm{Fe}_{3} \mathrm{O}_{4}-\mathrm{Fe}_{0.945} \mathrm{O}$ \\
$2 \_$exp & 920 & 1 & Based on experimental data (Table 4) \\
3 & 920 & 20 & $\zeta_{\mathrm{C} \text { to gas }}=100 \%$ : equilibrium in the gas phase for the reaction of $\mathrm{Fe}_{3} \mathrm{O}_{4}-\mathrm{Fe}_{0.945} \mathrm{O}$ \\
\hline
\end{tabular}

${ }^{a} \zeta_{\mathrm{C}}$ to gas: carbon to gas conversion. Is the molar fraction of carbon from the oil that is converted to gaseous compounds

b The $\zeta_{\mathrm{C}}$ to gas and gas composition were obtained from experimental measurements, in which the final gas composition after combined oil gasification and iron oxide reduction was measured (Bleeker et al. to be published) 
Fig. 8 Process flow sheet for the steam-iron process with pyrolysis oil feedstock

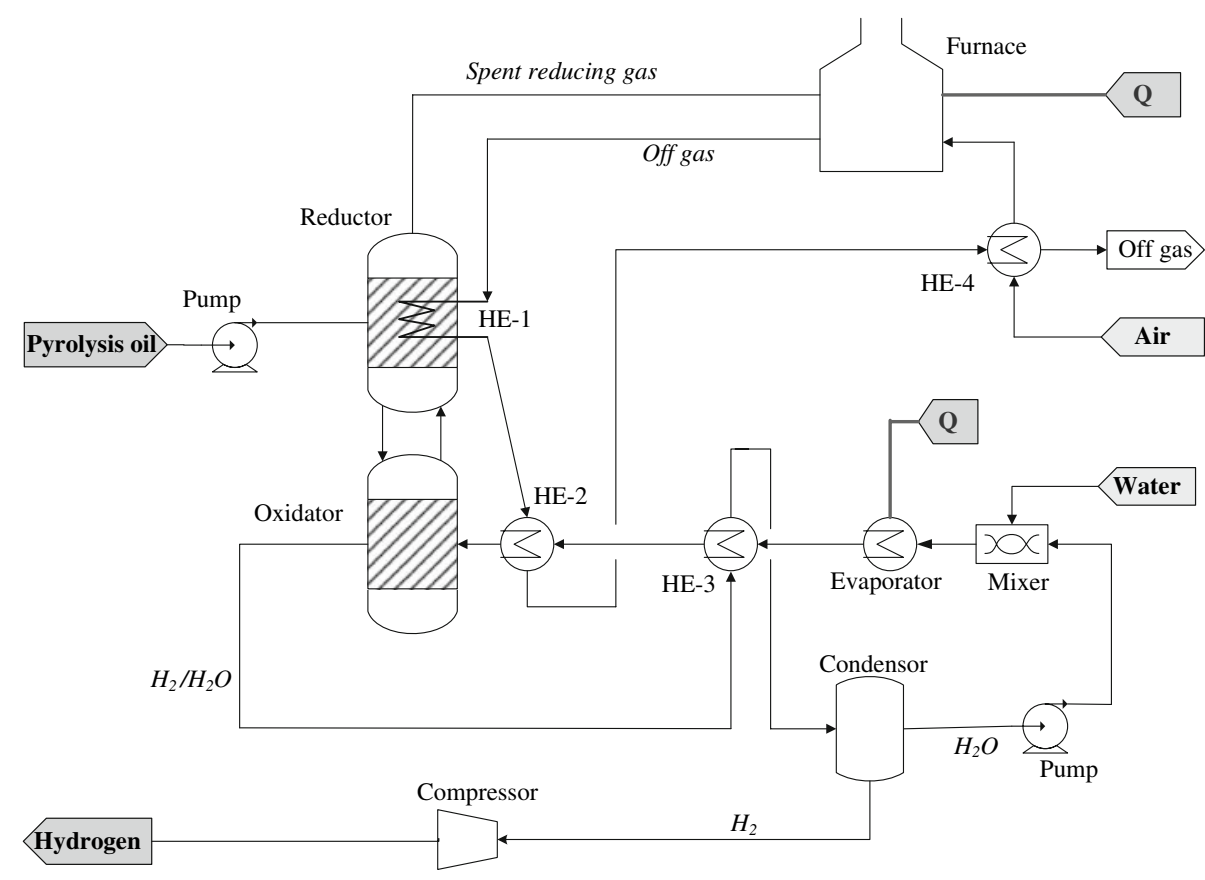

In this case, the full reduction potential of the pyrolysis oil is used, as the $\mathrm{CO} / \mathrm{CO}_{2}$ and $\mathrm{H}_{2} / \mathrm{H}_{2} \mathrm{O}$ ratios are the lowest for the reduction to wustite. Carbon, which is not contributing to the reduction, is combusted in the furnace (Table 4). For the experimental cases, the gas composition measured after oil gasification and iron oxide reduction is used.

The extent of conversion of the iron oxide during reduction determines the amount of hydrogen formed from steam in the oxidation. It is assumed that the oxidation to magnetite is complete and that the equilibrium steam conversion is obtained at the applied oxidation temperature.

Heat exchange

\section{Reductor/oxidator}

The energy produced in the exothermic oxidation supplies part of the energy required for the gasification/reduction reactor. This energy produced in the oxidation is transported by the iron oxide particles to the reduction reactor.

Table 4 Gas composition of the spent reducing gas after reduction of magnetite to wustite

\begin{tabular}{|c|c|c|c|c|c|c|}
\hline & \multicolumn{6}{|l|}{ Case } \\
\hline & $1 \mathrm{a}$ & $1 \mathrm{~b}$ & 1_exp & 2 & 2_exp & 3 \\
\hline$P$ (bar) & 1 & 1 & 1 & 1 & 1 & 20 \\
\hline$T\left({ }^{\circ} \mathrm{C}\right)$ & 800 & 800 & 800 & 920 & 920 & 920 \\
\hline \multicolumn{7}{|l|}{ Component (mole/kg oil) } \\
\hline $\mathrm{CH}_{4}$ & 1.0 & 0.1 & 2.6 & 0.1 & 3.5 & 5.4 \\
\hline $\mathrm{C}_{2}^{+}$ & - & - & 1.0 & - & - & - \\
\hline $\mathrm{CO}$ & 11.4 & 8.9 & 8.1 & 9.5 & 7.3 & 8.0 \\
\hline $\mathrm{H}_{2}$ & 17.3 & 18.1 & 13.2 & 11.0 & 6.7 & 8.4 \\
\hline $\mathrm{CO}_{2}$ & 18.4 & 14.3 & 12.3 & 21.3 & 14.1 & 17.8 \\
\hline $\mathrm{H}_{2} \mathrm{O}$ & 25.9 & 26.9 & 18.9 & 34.0 & 25.7 & 26.3 \\
\hline$C_{\text {solid }}$ & - & 7.7 & 5.9 & - & 5.9 & - \\
\hline LHV gas (MJ/kg oil) & 7.4 & 10.0 & 9.2 & 5.4 & 8.8 & 8.6 \\
\hline \multicolumn{7}{|l|}{ Redox } \\
\hline$\Delta \mathrm{O}(\mathrm{mole} / \mathrm{kg}$ oil $)$ & 40.3 & 30.6 & 18.6 & 52.4 & 27.6 & 35.4 \\
\hline $\mathrm{H}_{2}$ product $\left(\mathrm{Nm}^{3} / \mathrm{kg}\right.$ dry oil $)$ & 1.35 & 1.02 & 0.62 & 1.75 & 0.92 & 1.18 \\
\hline
\end{tabular}


To do so, a temperature gradient over both reactors is established; and during the process of reduction temperature decreases and during oxidation, temperature increases. The temperature change in the reactors depends on the amount of iron oxide circulated per amount of pyrolysis oil injected. The iron oxide to oil mass ratio is assumed to be $60\left(\mathrm{Fe}_{3} \mathrm{O}_{4} / \mathrm{oil}\right)$ and the temperature gradient is calculated using this ratio. The energy exchanged by the solids covers the energy required for the endothermic reduction reactions. However, the energy required for the gasification still needs to be supplied to the reduction reactor. This is done by heat exchange (HE 1) with the off gas obtained from the furnace. Therefore, in the energy balances the following relation is used:

Offgas $($ sensible heat $)=Q_{\text {reductor }}+Q_{\text {oxidator }}$

In an ideal fluidized bed, no temperature profiles are expected due to the good mixing of the solid particles. The equilibrium conditions are, therefore, based on the temperature at which the solids are exiting the reactor. Therefore, the temperature of the reductor $\left(T_{\text {red }}\right)$ is lower compared with oxidator $\left(T_{\mathrm{ox}}\right)$.

\section{Combustion spent gases}

Energy for the process can be obtained by the combustion of the spent gases. This is performed in a furnace in which the off gas can achieve a maximum temperature of $1,000^{\circ} \mathrm{C}$. The hot-off gas obtained is used for heat exchange with the gasification/reduction reactor (HE 1). The amount of air used in the furnace is adjusted to meet up the energy requirement in HE 1 (to fulfil equation 2). A surplus of energy in the furnace $\left(Q_{\text {furnace }}<0\right)$ is obtained when the energy content in the spent gas is more than sufficient to heat the off gas, in which case this energy is used in the evaporator for steam production. There is an energy demand in the furnace if $Q_{\text {furnace }}>0$, which can be fulfilled by the combustion of additional energy sources, such as pyrolysis oil. The off gas is further used to preheat the steam to the required oxidation temperature (HE 2) and for the preheating of the air feed (HE 4) to the furnace.

\section{Steam production}

The required hot steam for the oxidation is preheated by heat exchanging with the product stream of the oxidation reactor (HE 3). The steam input is preheated to the reduction temperature $\left(T_{\text {red }}\right)$. Owing to the exothermic reaction, the iron oxide and gases are heated to the oxidation temperature $\left(T_{\mathrm{ox}}\right)$ and the final $\mathrm{H}_{2} / \mathrm{H}_{2} \mathrm{O}$ product exits the oxidator at $T_{\mathrm{ox}}$. The energy content of the $\mathrm{H}_{2} / \mathrm{H}_{2} \mathrm{O}$ stream depends on the hydrogen content and the final oxidation temperature. The evaporator preheats the water and vaporizes the water to steam at $100^{\circ} \mathrm{C}(1 \mathrm{bar})$ and $215^{\circ} \mathrm{C}$ (at $20 \mathrm{bar}$ ). The energy required for the evaporation is obtained from the furnace and by hot utilities.

\section{Results}

To compare the overall energy efficiency of the different cases, mass and energy balances are created for each case per kilogram of pyrolysis oil. The results will give more insight into the optimal process conditions to maximize the efficiency at which $1 \mathrm{~kg}$ of pyrolysis oil is converted into the hydrogen product.

Mass balances

The theoretical and experimental gas composition after reduction of the magnetite to wustite with oil is shown in Table 4. The equilibrium ratios for the conditions discussed are given in Table 9 in the appendix. The change in the oxygen content $(\Delta \mathrm{O})$, in the gas phase before and after reduction can be related to the amount of iron oxide reduced and can be used for the calculation of the amount of hydrogen produced in the oxidation (Table 4).

The reducing potential of the gasified oil at $920^{\circ} \mathrm{C}$ compared with $800^{\circ} \mathrm{C}$ is higher, resulting in more reduced iron oxide (Table 4). This results in a low-heating value of the gas obtained after reduction, as more $\mathrm{CO}$ and $\mathrm{H}_{2}$ react with the iron oxide at a high temperature. Increasing the pressure has a similar effect: the reducing potential is slightly lower, resulting in a higher net heating value of the spent reducing gas. The hydrogen production based on the experimental data is about half the value of the theoretical hydrogen production. The experimental data are obtained from experiments in which the $\mathrm{Fe}_{3} \mathrm{O}_{4} /$ oil ratio is 60 and equilibrium of the oil with the iron oxide is not obtained, which results in a low hydrogen production. Increasing the temperature results, for both the experimental and theoretical case, in an increase in the hydrogen production by almost a factor of 1.5. The amount of steam that passes through the oxidation reactor without reacting, increases with temperature (Table 5). The temperature increase during oxidation is also shown in Table 5 and the final $\mathrm{H}_{2} /$ $\mathrm{H}_{2} \mathrm{O}$ ratio is based on the calculated temperature.

\section{Energy balances}

A heat integration study using the data from both the reduction and oxidation was performed to determine the possibilities for heat exchange and to calculate the heat required for the different process steps for each case. The energy balance for the streams and processes in the redox 
Table 5 Mass balance over the oxidation for the different cases

\begin{tabular}{|c|c|c|c|c|c|c|}
\hline & \multicolumn{6}{|c|}{ Cases } \\
\hline & $1 \mathrm{a}$ & $1 b$ & 1_exp & 2 & 2_exp & 3 \\
\hline$P$ (bar) & 1 & 1 & 1 & 1 & 1 & 20 \\
\hline$T_{\text {red }}\left({ }^{\circ} \mathrm{C}\right)$ & 800 & 800 & 800 & 920 & 920 & 920 \\
\hline$T_{\mathrm{ox}}\left({ }^{\circ} \mathrm{C}\right)$ & 848 & 838 & 823 & 979 & 961 & 970 \\
\hline \multicolumn{7}{|c|}{ Stream (mol/kg oil) } \\
\hline $\mathrm{H}_{2} \mathrm{O}$, in & 120 & 88 & 50 & 258 & 128 & 169 \\
\hline $\mathrm{H}_{2}$ & 40 & 31 & 19 & 52 & 28 & 35 \\
\hline $\mathrm{H}_{2} \mathrm{O}$, out & 80 & 57 & 32 & 206 & 100 & 133 \\
\hline
\end{tabular}

process are calculated and the energy demand of the processes is shown in Table 6.

The energy required in the reductor $\left(Q_{\text {reductor }}\right)$ is supplied by the exothermic oxidation reactor and the off gas from the furnace. The energy requirements for the gasification and reduction can be completely covered with the energy obtained from the combustion of the spent reducing gases and unreacted coke at $800^{\circ} \mathrm{C}\left(Q_{\text {furnace }}<0\right)$. However, $Q_{\text {furnace }}$ is positive when the reduction is performed at $920^{\circ} \mathrm{C}$ for case 2 , indicating that an additional energy source needs to be supplied to the furnace.

The high-energy demand in the reductor is mainly caused by the simultaneous gasification and reduction. Pyrolysis oil consists of a large fraction of water ( $\pm 30 \mathrm{wt} \%$ ), which is to be evaporated when gasified, resulting in a high-energy demand. It would be beneficial to evaporate the pyrolysis oil at a temperature of about $500^{\circ} \mathrm{C}$, before the gasification/reduction. In that case, the total energy demand would not change, but only the temperature at which it is required. This would, especially, be beneficial for the cases performed at $920^{\circ} \mathrm{C}$.

For the cases described here, the final off gas temperature (after HE4) is about $70-115^{\circ} \mathrm{C}$ and combined with the

Table 6 Energy requirement of the different process steps $(\mathrm{MJ} / \mathrm{kg}$ oil) in the redox cycle process with pyrolysis oil

\begin{tabular}{|c|c|c|c|c|c|c|c|}
\hline & \multicolumn{7}{|l|}{ Case } \\
\hline & $1 \mathrm{a}$ & $1 b$ & 1_exp & 2 & 2_exp & 3 & 3_mem \\
\hline$P$ (bar) & 1 & 1 & 1 & 1 & 1 & 20 & 20 \\
\hline$T_{\text {red }}\left({ }^{\circ} \mathrm{C}\right)$ & 800 & 800 & 800 & 920 & 920 & 920 & 920 \\
\hline $\mathrm{T}_{\mathrm{ox}}\left({ }^{\circ} \mathrm{C}\right)$ & 848 & 838 & 823 & 979 & 955 & 970 & 970 \\
\hline \multicolumn{8}{|c|}{ Process step (MJ/kg oil) } \\
\hline Reductor & 8.4 & 6.9 & 5.4 & 9.9 & 6.5 & 7.7 & 7.7 \\
\hline Oxidator & -2.5 & -2.0 & -1.2 & -3.1 & -1.8 & -2.6 & -2.6 \\
\hline Furnace & -2.1 & -4.9 & -5.5 & 2.3 & -3.9 & -2.9 & -2.8 \\
\hline Evaporator & 4.9 & 3.6 & 2.1 & 10.7 & 5.2 & 6.2 & 1.8 \\
\hline Condenser & -3.3 & -2.3 & -1.3 & -8.5 & -4.0 & -4.7 & - \\
\hline Compressor & 0.66 & 0.50 & 0.30 & 0.83 & 0.50 & - & 0.58 \\
\hline
\end{tabular}

large quantities of air, results in a substantial energy loss (2.5-3.6 MJ/kg oil, condensation enthalpy $\mathrm{H}_{2} \mathrm{O}$ not included). The energy required in the evaporator has to be supplied by the surplus of energy in the furnace or externally. The energy demand of the evaporator is at a relatively low temperature and could therefore also be supplied by waste energy streams from close by facilities. The hydrogen product is separated from the steam fraction by condensation in the condenser, resulting in a substantial energy loss $\left(Q_{\text {condenser }}\right)$, as the condensation enthalpy cannot be recovered. It can be clearly seen that the loss of energy in the condenser is increasing with increasing oxidation temperature. Therefore, an additional case (3 mem) is discussed in the next section, in which the separation of the $\mathrm{H}_{2} / \mathrm{H}_{2} \mathrm{O}$ mixture is performed using membranes.

In case 3, the energy required to pump water to a pressure of $20 \mathrm{bar}(4 \mathrm{~kJ} / \mathrm{kg}$ oil feed) or to pump pyrolysis oil to $20 \mathrm{bar}(6 \mathrm{~kJ} / \mathrm{kg}$ oil) is small and negligible compared with the other energy streams shown.

Discussion on the energy balances of the different cases

\section{Case $1 a, 1 b$ and 1_exp}

The heat provided by the combustion of the spent reaction gases can supply the heat required for gasifying the pyrolysis oil and evaporating the steam for the oxidation in case $1 \mathrm{~b}$ and 1_exp. In both cases, not the full potential of oil for the reduction was used, which resulted in a sufficient heating value of the spent gas to supply the energy for both the reductor and evaporator. In case 1a on the other hand, this was not the case and additional energy was required in the evaporator.

\section{Case 2 and 2_exp}

The hydrogen production for case 2 is high, but the results in a high-energy demand in the reductor and evaporator. Furthermore, the temperature increase in the oxidator is high $\left(59^{\circ} \mathrm{C}\right)$, caused by the relatively high conversion of the iron oxide. Both effects result in an overall high-energy demand, mostly needed for the evaporation of the water feed. At temperatures above $900^{\circ} \mathrm{C}$, the unfavorable $\mathrm{H}_{2} /$ $\mathrm{H}_{2} \mathrm{O}$ equilibrium in the oxidation is a bottleneck for energy efficient processing. When the process is operated at 20 bar; however, it is also possible to separate the hydrogen product by membrane modules, lowering the energy required as condensation can be prevented in this situation (see case 3_mem). Another option is to use the product obtained from the oxidation reactor in a PEM fuel cell. In such a fuel cell, a feed consisting of a molar $\mathrm{H}_{2} \mathrm{O} / \mathrm{H}_{2}$ ratio of 2 is required, as the protons migrate as $\mathrm{H}_{3} \mathrm{O}^{+}$ions through the membrane. 
The complete separation of hydrogen from the product gas is in this case not necessary. The obtained $\mathrm{H}_{2} / \mathrm{H}_{2} \mathrm{O}$ (gas phase) product could then directly be supplied to a fuel cell for electricity production on site.

\section{Case 3 and 3_mem}

Case 3 is similar to case 2, but due to the enhanced pressure, the reduction potential of the oil is decreased. Therefore, the heating value of the spent gases is sufficient to supply the energy for the reductor. It is possible to use $\mathrm{Pd} / \mathrm{Ag}$ membrane modules for the separation of steam from the steam/ hydrogen product (Smith and Shantha 2007; Sjardin et al. 2006; Hou and Hughes 2003), when the process is operating at 20 bar. To separate hydrogen from water at temperatures between 400 and $500^{\circ} \mathrm{C}$ permeation fluxes up to $8 \mathrm{~m}^{3} / \mathrm{m}^{2} \mathrm{~h}$ (Sjardin et al. 2006) can be achieved. This results in membrane modules of $0.098 \mathrm{~m}^{2} \mathrm{~h} / \mathrm{kg}$ oil when a flux of $0.8 \mathrm{Nm}^{3}$ $\mathrm{H}_{2} / \mathrm{kg}$ oil needs to be achieved (case 3_mem). The main advantage of this separation is that only an equal molar amount of water, compared with hydrogen product, has to be evaporated to steam. The hydrogen product will in this case be delivered at a pressure between 1 and 2 bar (Sjardin et al. 2006; Hou and Hughes 2003) and needs to be compressed to a pressure of 20 bar (product specification). In the calculations, it was assumed that the membrane separation takes place at $400^{\circ} \mathrm{C}$.

\section{Combined mass and energy balances}

The overall heat requirement for the process $(Q>0)$ for all cases is the amount of energy required in the furnace plus the amount of energy required in the evaporator:

$Q=Q_{\text {furnace }}+Q_{\text {evaporator }}$

Only the energy requirements are taken into account in the overall hydrogen efficiency calculation. The overall balances for all cases are summarized in Table 7. With the combined mass and energy balances, overall process efficiencies could be determined (using Eq. 1). The efficiencies found are lower or in the same range compared with typical hydrogen from biomass process efficiencies, which are in the LHV/LHV values between 50 and 58\% (Hamelinck and Faaij 2002).

An increased temperature has a negative influence on the overall process efficiency from a theoretic point of view (compare case 1a and 2). More hydrogen per $\mathrm{kg}$ oil is produced at $920^{\circ} \mathrm{C}$, but a lot of energy is wasted in the oxidation, resulting in a high-energy demand process.

When it is assumed that not the full reduction potential of the oil can be used, due to incomplete conversion of oil to the gas phase (case $1 \mathrm{~b}$ ) at $800^{\circ} \mathrm{C}$, the overall efficiency decreases. However, the efficiency is still comparable with the efficiency obtained at high temperature. Thus, when
Table 7 Process efficiencies of the different cases

\begin{tabular}{lllllllll}
\hline & \multicolumn{1}{l}{ Cases } \\
\cline { 2 - 8 } & $1 \mathrm{la}$ & $1 \mathrm{~b}$ & 1_exp & 2 & 2_exp & 3 & $\begin{array}{l}3 \\
\text { mem }\end{array}$ \\
\hline $\begin{array}{c}\mathrm{H}_{2} \text { production }\left(\mathrm{Nm}^{3} /\right. \\
\mathrm{kg} \text { dry oil) }\end{array}$ & 1.35 & 1.02 & 0.62 & 1.75 & 0.92 & 1.18 & 1.18 \\
$Q(\mathrm{MJ} / \mathrm{kg}$ oil $)$ & 2.8 & - & - & 13.0 & 1.3 & 3.3 & - \\
$W_{\text {comp }}(\mathrm{MJ} / \mathrm{kg}$ oil $)$ & 0.66 & 0.50 & 0.30 & 0.85 & 0.45 & - & 0.56 \\
$\eta_{\text {process }}(\mathrm{LHV} / \mathrm{LHV})$ & 0.53 & 0.47 & 0.29 & 0.46 & 0.39 & 0.48 & 0.54 \\
\hline
\end{tabular}

equilibrium can be obtained in the gas phase a low temperature is preferred to a high temperature, even when a substantial amount of the oil (25\% of the carbon input) is not participating in the reduction reactions. In fact, a surplus of energy was produced $(1.3 \mathrm{MJ} / \mathrm{kg}$ oil) in case $1 \mathrm{~b}$, which was not needed in the process.

An increased pressure at high temperatures results in an improved efficiency, which can be further improved when separation of $\mathrm{H}_{2}$ from $\mathrm{H}_{2} \mathrm{O}$ is performed using a membrane. The efficiency in this case is similar to commercial biomass to hydrogen production processes with an extra energy production of $1 \mathrm{MJ} / \mathrm{kg}$ oil obtained from the furnace.

For the experimental cases, the opposite is true; a high temperature (case 2_exp) is preferential to a low temperature (case 1_exp). This is caused by the low hydrogen production at low temperatures. Apparently, the gasification/reduction reactions are not sufficient at this temperature, resulting in a low conversion in the reductor. The conversion of oil to pure hydrogen can be improved (based on experimental data) by increasing the $\mathrm{Fe}_{3} \mathrm{O}_{4}$ /oil ratio (Bleeker et al. 2007).

\section{Conclusions}

The overall energy efficiency for the production of pure hydrogen using the pyrolysis oil-driven steam-iron process is evaluated for different process conditions. The used process consists of a two-step process from which relatively pure renewable hydrogen can be obtained, without the need of any purification steps. An energy efficiency (LHV based) of $53 \%$ is achieved when the equilibrium conversion is reached in the redox cycle with pyrolysis oil at $800^{\circ} \mathrm{C}$, which is similar to other thermochemical biomass to hydrogen routes $(50-58 \%)$. The use of pyrolysis oil in the steam-iron process for the production of hydrogen is energy efficient, based on the equilibrium calculations. However, experimental results showed that this theoretical efficiency could not be achieved. Possible improvements to increase the efficiency are (1) improving the iron oxide material to increase the conversion during reduction at $800^{\circ} \mathrm{C}$ or by (2) membranes for the separation of steam from the hydrogen product at high process temperatures $\left(>900^{\circ} \mathrm{C}\right)$. 
Acknowledgment The authors gratefully acknowledge the funding support within the Sustainable Hydrogen Program of ACTS/NWO in The Netherlands.

Open Access This article is distributed under the terms of the Creative Commons Attribution Noncommercial License which permits any noncommercial use, distribution, and reproduction in any medium, provided the original author(s) and source are credited.

\section{Appendix}

The calculations discussed in this paper are all based on the oil input data shown in Table 8. The elemental composition of pyrolysis oil, however, depends on many factors,

Table 8 Pyrolysis oil input data

\begin{tabular}{|c|c|c|c|c|c|c|}
\hline & & $\mathrm{C}$ & $\mathrm{H}$ & $\mathrm{O}$ & & $\mathrm{H}_{2} \mathrm{O}$ \\
\hline \multicolumn{7}{|c|}{ Elemental pyrolysis oil composition } \\
\hline \multicolumn{2}{|c|}{ Pyrolysis oil (wet) wt $\%$} & 0.37 & 0.09 & $0.54^{\mathrm{a}}$ & & 0.32 \\
\hline \multicolumn{2}{|c|}{ Pyrolysis oil (dry) wt\% } & 0.54 & 0.08 & 0.38 & & \\
\hline Mole fractions & Mole\% & $\mathrm{C}$ & $\mathrm{H}$ & & $\mathrm{O}$ & \\
\hline \multicolumn{7}{|c|}{ Feed simulation of the pyrolysis oil by using two model compounds } \\
\hline Oil & 1 & 0.30 & \multicolumn{2}{|l|}{0.54} & \multicolumn{2}{|c|}{0.16} \\
\hline Simulated oil & 1 & 0.31 & \multicolumn{2}{|l|}{0.54} & 0.15 & \\
\hline $\mathrm{C}_{6} \mathrm{H}_{10} \mathrm{O}_{3}$ & \multicolumn{6}{|l|}{0.66} \\
\hline \multirow[t]{2}{*}{$\mathrm{C}_{6} \mathrm{H}_{12} \mathrm{O}_{3}$} & \multicolumn{6}{|l|}{0.34} \\
\hline & \multicolumn{2}{|c|}{ LHV (MJ/kg) } & \multicolumn{3}{|c|}{$\Delta H_{\mathrm{f}}(\mathrm{MJ} / \mathrm{kg})^{\mathrm{b}}$} & \\
\hline \multicolumn{7}{|c|}{ Energy data of pyrolysis oil (Phyllis) } \\
\hline $\mathrm{H}_{2}$ & \multicolumn{2}{|c|}{121} & & & & \\
\hline Pyrolysis oil (dry) & \multicolumn{2}{|l|}{22.4} & \multicolumn{4}{|l|}{-5.3} \\
\hline Pyrolysis oil (wet) & \multicolumn{2}{|l|}{15.2} & \multicolumn{4}{|l|}{-8.7} \\
\hline
\end{tabular}

${ }^{a}$ Determined by difference

b The heat of formation of dry pyrolysis oil, required to calculate reaction enthalpy of the gasification, needed to be determined. The heat of formation is calculated using the LHV and the elemental composition of oil

Table 9 Equilibrium ratios of $\mathrm{CO} / \mathrm{CO}_{2}$ and $\mathrm{H}_{2} / \mathrm{H}_{2} \mathrm{O}$ for the reduction of magnetite to wustite

\begin{tabular}{lccc}
\hline & \multicolumn{2}{c}{ Case } & \\
\cline { 2 - 4 } & $1 \mathrm{a}, \mathrm{b}$ & 2 & 3 \\
\hline$P$ (bar) & 1 & 1 & 20 \\
$T_{\text {red }}\left({ }^{\circ} \mathrm{C}\right)$ & 800 & 920 & 920 \\
Equilibrium ratio (molar) & & \\
$\mathrm{CO} / \mathrm{CO}_{2}$ & 0.62 & 0.45 & 0.45 \\
$\mathrm{H}_{2} / \mathrm{H}_{2} \mathrm{O}$ & 0.67 & 0.32 & 0.32 \\
\hline
\end{tabular}

such as biomass feed used and process conditions of the pyrolysis process. Therefore, the obtained results may fluctuate with the pyrolysis feed used. The equilibrium data of the iron oxide used for the different cases is shown in Table 9.

\section{References}

Bleeker MF, Kersten SRA, Veringa HJ (2007) Pure hydrogen from pyrolysis oil using the steam-iron process. Catal Today 127: 278-290

Bridgwater AV (2002) Fast pyrolysis of biomass: a handbook, vol 2. CPL Press, Newbury

Bridgwater AV (2004) Biomass fast pyrolysis. Therm Sci 8:21-49

Cheng X, Shi Z, Glass N, Zhang L, Zhang J, Song D, ZSh Liu, Wang $\mathrm{H}$, Shen J (2007) A review of PEM hydrogen fuel cell contamination: impacts, mechanisms, and mitigation. J Power Sources 165:739-756

Chilukuri P, Rademakers K, Nymeijer K, van der Ham L, van den Berg H (2007) Propylene/propane separation with a gas/liquid membrane contactor using a silver salt solution. Ind Eng Chem Res 46:8701-8709

Gasior SJ (1961) Production of synthesis gas and hydrogen by the steam-iron process: pilot plant study of fluidized and free-falling beds. Bureau of Mines, Washington

Hacker V (2003) A novel process for stationary hydrogen production: the reformer sponge iron cycle (RESC). J Power Sources 118:311-314

Hacker V, Fankhauser R, Faleschini G, Fuchs H, Friedrich K, Muhr M, Kordesch K (2000) Hydrogen production by steam-iron process. J Power Sources 86:531-535

Hamelinck CN, Faaij APC (2002) Future prospects for production of methanol and hydrogen from biomass. J Power Sources 111: $1-22$

Hou K, Hughes R (2003) Preparation of thin and highly stable Pd/Ag composite membranes and simulative analysis of transfer resistance for hydrogen separation. J Membr Sci 214:43-55

Kersten SRA et al (2003) Experimental fact-finding in CFB biomass gasification for ECN's $500 \mathrm{kWth}$ pilot plant. Ind Eng Chem Res 42:6755-6764

Phyllis, Database for biomass and waste, www.ecn.nl/phyllis, last visit 12 Feb 2009, Energy research Centre of the Netherlands

Raissi A, Block DL (2004) Hydrogen: automotive fuel of the future. IEEE Power Energy Mag 6:40-45

Ramage PR, Agrawal R (2004) The hydrogen economy: opportunities, costs barriers and R\&D needs. The National Academies, National Academies Press, Washington DC

Sjardin M, Damen KJ, Faaij APC (2006) Techno-economic prospects of small-scale membrane reactors in a future hydrogen-fuelled transportation sector. Energy 31:2523-2555

Smith B, Shantha MS (2007) Membrane reactor based hydrogen separation from biomass gas: a review of technical advancements and prospects. Int J Chem Reactor Eng 5:A84

Spath PL, Mann MK, Amos WA (2003) Update of hydrogen from biomass-determination of the delivered cost of hydrogen, NREL/MP-510-33112, National Renewable Energy Laboratory, Golden, CO

Tarman PB, Biljetina R (1979) Hydrogen by the steam-iron process. Coal Proc Tech 5:114-116

Yanga C, Ogdena J (2007) Determining the lowest-cost hydrogen delivery mode. Int J Hydrogen Energy 32:268-286 